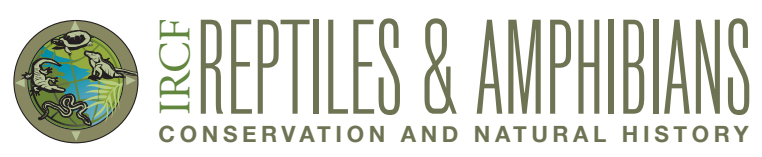

\title{
Extension of the Known Range of the Trinket Snake, Coelognathus helena nigriangularis (Reptilia: Squamata: Colubridae), in India
}

\author{
Subhadeep Chowdhury ${ }^{1}$, Ranadeep Sengupta ${ }^{2}$, Shibajee Mitra ${ }^{3}$, and Anirban Chaudhuri ${ }^{4}$ \\ ${ }^{1}$ Krishnachak, Dhurkhali, Howrah 711410, West Bengal, India \\ ${ }^{2} 14$ Garia Place (North), Kolkata 700084, West Bengal, India \\ ${ }^{3}$ Badu Reptile Conservation Society, Badu, Kolkata 700128, West Bengal, India \\ ${ }^{4}$ Nature Mates Nature Club, 6/7, Bijoygarh, Jadavpur, Kolkata 700032, West Bengal, India (abchaudhuri@gmail.com)
}

$\mathrm{T}$ he genus Coelognathus (Fitzinger 1843) currently comprises seven species, of which three, C. flavolineatus (Schlegel 1837), C. helena (Daudin 1803), and C. radiatus (Boie 1827), are known to occur in India (Schulz 2013). Coelognathus helena currently comprises three recognized subspecies, $C$. h. helena (Daudin 1803), C. h. montilocollaris (Schulz 1992), and the recently described C. h. nigriangularis (Mohapatra, Schulz, Helfenberger, Hofmann, and Dutta 2016). The latter inhab- its dry and moist tropical deciduous forests where it has been encountered under piles of rock boulders and inside limestone caves (Mohapatra et al. 2016). Edake (2011) found one individual hidden under bamboo leaves. Like the other conspecific taxa, this subspecies is crepuscular by nature and preys primarily on small mammals (Mohapatra et al. 2016).

Coelognathus helena helena can be identified in the field by the uniform twin-striped neck marking (Whitaker and

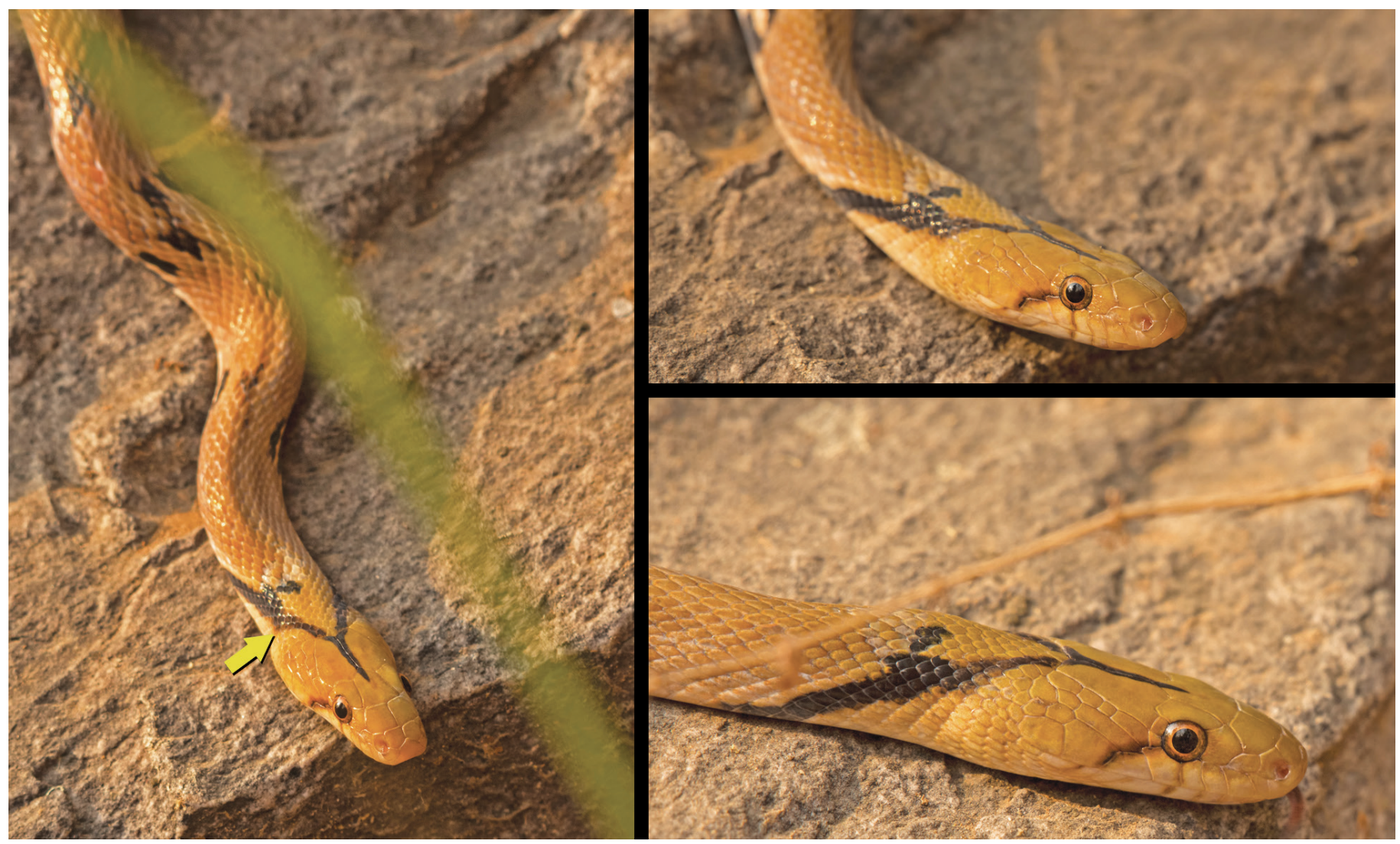

Fig. 1. A Trinket Snake (Coelognathus helena nigriangularis) from the Susunia Hills, West Bengal, India. Photographs by Ranadeep Sengupta. 


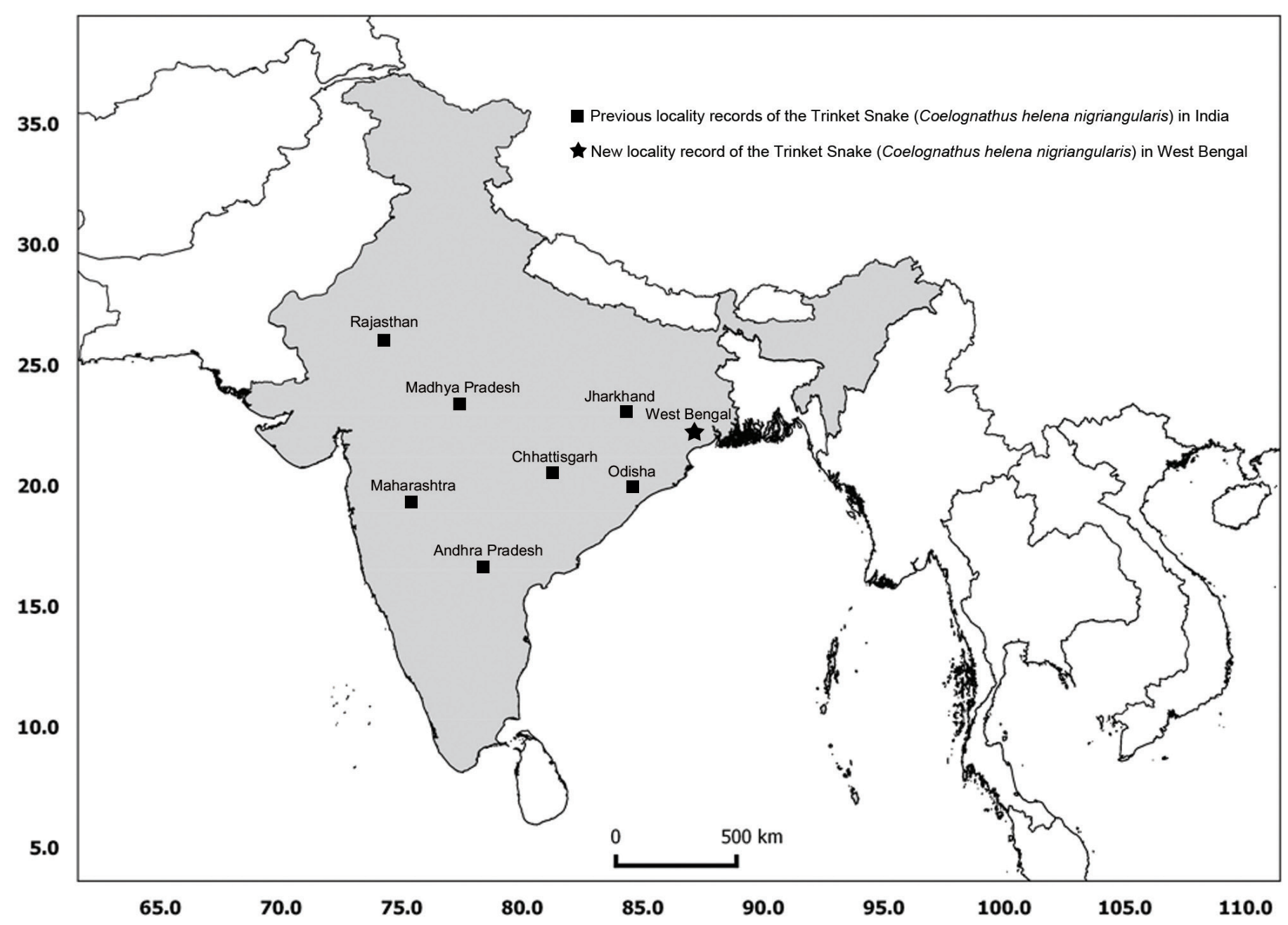

Fig. 2. Map of India showing previously published locality records and a new record for the Trinket Snake (Coelognathus helena nigriangularis).

Captain 2008; Mohapatra et al. 2016), C. h. monticollaris can be distinguished by a round necklace-like nuchal pattern (Mohapatra et. al 2016), and C. h. nigriangularis can easily be diagnosed by the prominent black inverted V- or Y-shaped marking on the ventrolateral side of the neck near the base of the parietal shields (Mohapatra et al. 2016). In some individuals, the pointed end of the inverted $\mathrm{V}$ or $\mathrm{Y}$ extends to the frontal shield (Fig. 1; photographic voucher, Lee Kong Chian Natural History Museum, National University of Singapore, ZRC(IMG) 2.381a-c).

The known range of C. h. nigriangularis (Fig. 2) consists of scattered records in parts of Chhattisgarh and the state of Odisha (Mohapatra et al. 2016). The subspecies also has been recorded from the states of Madhya Pradesh (Edake 2011; Kumbhar et al. 2011), Maharashtra (Schulz 2013), Jharkhand (Lampe and Lindholm 1902; Srivastava et al. 2013), and Andhra Pradesh (Kantimahanti et al. 2015) in India. A specimen in the Bombay Natural History Society Museum (BNHS 3374) was examined by Mohapatra et al. (2016); it originated from Rajasthan, India, but lacked specific locality data.
Here we report the occurrence of $C$. helena nigriangularis from the Susunia Hills region in the northwestern Bankura District of southern West Bengal, India $\left(23.395525^{\circ} \mathrm{N}\right.$, $86.986439^{\circ} \mathrm{E}$; elev. $410 \mathrm{~m}$ asl; Fig. 2). RS encountered the snake at $0905 \mathrm{~h}$ on 17 December 2016 with the anterior part of its body extending out of a rocky crevice. It was then photographed from a distance, and when approached it retreated inside the crevice. The rocky area where the snake was found lacked substantive vegetation but a few small bushes and shrubs were in the area. This new locality record for the subspecies extends its northeastern-most distribution by approximately $311 \mathrm{~km}$ and $358 \mathrm{~km}$ from the nearest previously recorded locations in the states of Jharkhand and Odisha, respectively.

\section{Acknowledgement}

The authors thank Milind Mutnale for providing the outline map.

\section{Literature Cited}

Edake, S. 2011. Serpents of Bandhavgarh. Trustees of the Corbett Foundation Newsletter, October-December 2010 \& January-March 2011: 1-8. 
Kantimahanti, M., K.D. Schulz, and V. Sharma. 2015. New locality records of Coelognathus helena cf. monticollaris (Schulz, 1992) from Andhra Pradesh, India. Sauria 37(4): 71-74.

Kumbhar A.S., G.C Patwardhan, A.K Pradhan, and N.S Dungriyal. 2011. New locality record of Coelognathus helena monticollaris (Schulz, 1992) from central India. Cobra 5(2): 31-35.

Lampe, E. and W.A. Lindholm. 1902. Catalog der Reptilien- und AmphibienSammlung (Schlangen; Frosch-, Schwanz- und Schleichenlurche) des Naturhistorischen Museums zu Wiesbaden. Jahrbücher des Nassauischen Vereins für Naturkunde 55: 1-66.

Mohapatra, P.P., K.D. Schulz, N. Helfenberger, S. Hofmann, and S.K. Dutta.
2016. A contribution to the Indian Trinket Snake, Coelognathus helena (Daudin, 1803), with the description of a new subspecies. Russian Journal of Herpetology 23: 115-144.

Schulz, K.D. 2013. An annotated and illustrated checklist of Old World ratsnakes, pp. 17-268. In: K.D. Schulz (ed.), Old World Ratsnakes. A Collection of Papers. Bushmaster Publications, Berg, Switzerland.

Srivastava D.S., P.S Easa, and J.B Jauher. 2013. Integrated Wildlife Management Plan for Singhbhum, Jharkhand. Unpublished Report Submitted to the Department of Forest and Environment. Government of Jharkhand, India.

Whitaker, R. and A. Captain. 2008. Snakes of India: The Field Guide. Draco Books, Chennai, India. 